\title{
Species diversity, functional complexity and rarity in Arctic fjordic versus open shelf benthic systems
}

\author{
Maria Włodarska-Kowalczuk ${ }^{1, *}$, Paul E. Renaud ${ }^{2}$, Jan Marcin Węsławski ${ }^{1}$, \\ Sabine K. J. Cochrane ${ }^{2}$, Stanislav G. Denisenko ${ }^{3}$ \\ ${ }^{1}$ Institute of Oceanology PAS, Powstańców Warszawy 55, 81-712 Sopot, Poland \\ ${ }^{2}$ Akvaplan-niva, Fram Centre for Climate and Environment, N-9296 Tromsø, Norway \\ ${ }^{3}$ Zoological Institute RAS, Universitetskaya nab. 1, 199034 St Petersburg, Russia
}

\begin{abstract}
We present a cross-system comparison of benthic species pools, species diversity, functional complexity and rarity in 2 typical Arctic coastal systems: an open shelf marginal sea and fjords (semi-enclosed, geologically younger basins remaining under strong terrestrial influences). A total of 388 van Veen grab samples were collected in the Barents Sea and 3 west Spitsbergen fjords (divided into inner and outer basins). Thirty percent of species were recorded only in fjords, questioning the common notion of the fjordic communities being merely subsets of the offshore species pools. Inner fjords, outer fjords and the open shelf hosted communities that differed significantly in terms of species composition and diversity. Species richness, examined at the scales of both the ecological zone and an individual sample, was severely depleted in inner fjordic basins. The congruence of the patterns across taxonomic groups employing different life histories (benthic vs. pelagic dispersal) pointed to habitat deterioration rather than dispersal barriers as a factor responsible for the fjordic diversity clines. The between-habitat differences in functional diversity were expressed in decreased functional evenness and a decline in suspension-feeding, sedentary and large tube-dwelling species in fjords, affecting infaunal habitat complexity. Species redundancy declined across the shelf - outer fjord-inner fjord environmental gradients, suggesting a higher resilience of shelf systems. The environmental deterioration of fjordic basins did not result in the reduction of rare species. These results should be applied to strategies for managing open shelf and fjordic habitats in the Arctic.
\end{abstract}

KEY WORDS: Biodiversity $\cdot$ Rarity $\cdot$ Functional diversity $\cdot$ Redundancy $\cdot$ Benthos $\cdot$ Arctic

\section{INTRODUCTION}

The interplay between local and regional processes has been recognized as an important driver of diversity patterns at different spatial scales (e.g. Huston 1999, Ricklefs 1987), but these issues have remained relatively poorly explored in marine systems (Smith 2001). Witman et al. (2004) showed that, on a global scale, local species richness is strongly related to regional species pools in epifaunal benthic communities encrusting subtidal rocks. For soft-bottom North Atlantic benthic communities, Renaud et al.
(2009) found a positive relationship between the local and regional species richness, while Somerfield et al. (2009) showed that at different spatial levels, local communities were not random subsets of regional species pools, and tended to be composed of species more closely related (i.e. having similar tolerances to environmental stressors and shared functional traits) than if selected randomly.

Fjords are semi-enclosed marine inlets that remain under strong terrestrial influences and are considered to be strongly dependent on regional species pools of neighboring open shelf seas (Pearson 1980). 
They are geologically young areas (produced after the last glacial maximum some 17000 years BP), and are regarded as ecologically immature, non-steadystate systems that have been evolving over relatively short time scales (Syvitski et al. 1987). Two mechanisms are usually cited as possible causes of the fjordic diversity impoverishment: (1) the barrier hypothesis points to the geomorphologic barriers that prevent a number of open shelf species from colonizing the fjordic habitats; (2) the habitat hypothesis states that lower diversity in fjords is due to the less favorable environment relative to offshore habitats (Buhl-Mortensen \& Höisæeter 1993). The barrier hypothesis assumes that shelf seas serve as local species pools for fjordic biocenosis. Fjord communities are often regarded as range extensions of shelf communities that are filtered by barrier or habitat filters.

In Arctic fjords, the main environmental gradients/ barriers are produced by the inflows of glacial meltwaters that are usually located in inner basins (Syvitski et al. 1987). Meltwaters are loaded with high levels of particulate mineral material, much of which sediments close to the glacial or glaciofluvial inflows (Syvitski et al. 1996, Zajączkowski \& WłodarskaKowalczuk 2007). In inner basins of west Spitsbergen fjords, the sedimentation rates in the water column can reach $2000 \mathrm{~g} \mathrm{~m}^{-2} \mathrm{~d}^{-1}$ on average, whereas the sediment deposition at the sea bottom was estimated to be up to $6-9 \mathrm{~cm} \mathrm{yr}^{-1}$ (Trusel et al. 2010). High sedimentation results in the formation of unconsolidated sediments that are easily eroded, frequently resuspended and redeposited and can be disturbed by iceberg scouring or catastrophic gravity flows (Syvitski et al. 1987, Zajączkowski \& Włodarska 2007). Longer persistence of fast ice cover and high water turbidity in the inner fjordic basins reduce pelagic primary production, and organic matter that sediments to the bottom is diluted by the high inorganic component. As a result, the organic matter content in sediments decreases along the gradient from the open shelf to the inner fjord glacial bays (Włodarska-Kowalczuk \& Pearson 2004, Winkelmann \& Knies 2005).

Functional diversity is based on understanding what organisms do in ecosystems rather than on evolutionary history as reflected in taxonomic relationships, and is proposed as a better determinant of the ecosystem processes than the traditional measures of species diversity (Petchey \& Gaston 2002). The relationships between species and functional diversity across different systems are poorly understood, and they are not necessarily strongly correlated. Thus, taxonomic diversity cannot serve as a universal surrogate for functional diversity (Micheli \& Halpern
2005). Concepts of complementarity and redundancy have enhanced our understanding of the importance of biodiversity in ecosystem stability and response (Naeem 1998, Loreau et al. 2001). Embedded in this discussion is the potential role of rare species. In many systems, a relatively large fraction of the taxa present are rare, occurring at few stations and/or at very low abundances (Gaston 1994). Little attention has been given to rare species in marine systems with respect to what proportion of the total biodiversity can be expected to be rare (but see Ellingsen et al. 2007), or how these taxa may operate in the community. The little evidence that exists, however, suggests that rare species may provide the buffer of functional redundancy and offer some indication of community stability (Death 1996). Rare species can play a major role in driving temporal changes in assemblages, for example under climatic or anthropogenic changes, because they appear to be much more sensitive to fluctuations in environmental conditions than abundant species (Benedetti-Cecchi et al. 2008). Documenting this element of regional biodiversity, therefore, may be important for both ecological understanding and ecosystem management.

Because of intensified impacts of climate change in Arctic regions (ACIA 2006), and the increase in human activities (e.g. tourism, petroleum exploration, fishing) driven by reduced ice cover, there is an urgent need for development of management and monitoring strategies that take into account an understanding of biodiversity and ecosystem function. It is unclear whether traditional indicators of system status and our understanding of ecological response are relevant in Arctic regions (e.g. Olsen et al. 2007). Further, it may be necessary to manage shelf and fjordic regions differently, and these contrasts must be accounted for when developing indicators (taxa, indices, etc.) and target values that are valid in this regional context.

Here we present a study based on an extensive data set including 388 samples collected in 3 high latitude Arctic fjords (west Spitsbergen) and in the neighboring open Arctic shelf sea (Barents Sea). The Barents Sea is noted as having the greatest biodiversity of all Arctic marginal seas (Sirenko 2001), perhaps because of the strong influence of both Arctic and Atlantic waters and the high productivity of the marine frontal systems. Macrobenthic communities of the Barents Sea have been thoroughly described (e.g. Denisenko et al. 2003, Denisenko 2004, Cochrane et al. 2009). Benthic communities of fjordic waters of the nearby Svalbard archipelago have also been subject to considerable study (e.g. Włodarska- 
Kowalczuk \& Węsławski 2001, Włodarska-Kowalczuk \& Pearson 2004, Renaud et al. 2007). No attempt has been undertaken, however, to compare these 2 neighboring marine systems. In this paper we specifically ask: (1) Are fjords only 'subsets' of the shelf species pool or are there species specific to both fjordic and shelf habitats/sub-habitats (thus questioning the basic assumption of the barrier hypothesis that the shelf species pool is the only source of species richness in fjords); (2) What are the diversity characteristics of the open sea and fjordic macrobenthic communities with regard to the species richness and diversity, assessed at different scales; (3) Are the patterns of species richness across the shelf and fjordic basins consistent across major taxonomic groups regardless of their dominant dispersal mode (thus questioning the barrier mechanisms); and (4) What is the distribution of functional groups (as a proxy of the functional complexity of the communities) and the percentages of rare species (as a proxy of the systems' vulnerability to species loss) in different ecological zones? The diversity assessment documented in the present study also provides baseline information for producing recommendations for

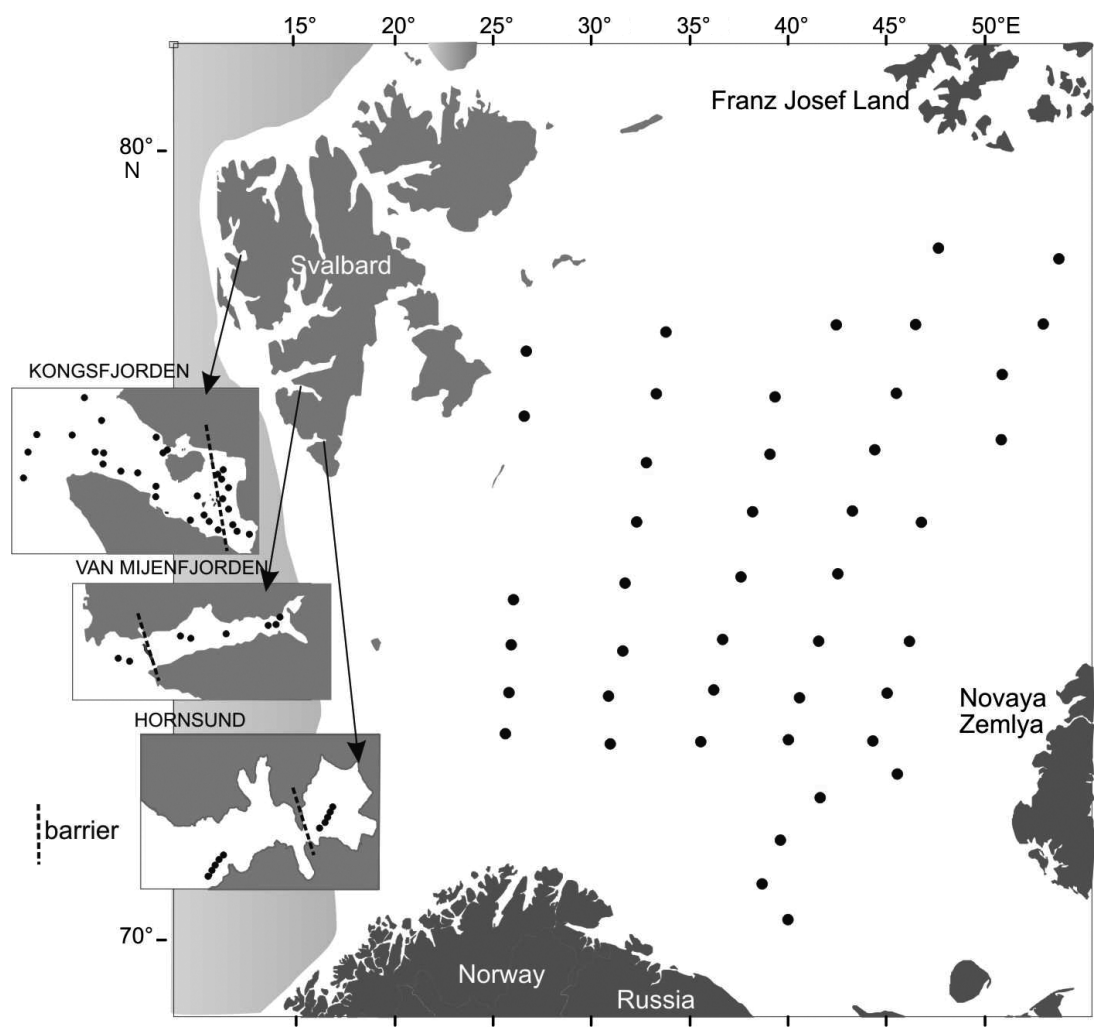

Fig. 1. Sampling area: Barents Sea shelf (white area) and Spitsbergen fjords (insets). The location of sampling stations $(\bullet)$ is presented together with the schematic location of the main barrier separating inner fjord from outer fjord basins in Kongsfjorden, van Mijenfjorden and Hornsund management and conservation of the marine benthic systems in Arctic open sea and semi-enclosed marine inlets.

\section{MATERIALS AND METHODS}

\section{Sampling and laboratory analysis}

This study is based on material collected in the Barents Sea and in 3 west Spitsbergen fjords (Kongsfjorden, van Mijenfjorden and Hornsund) during several expeditions that took place from 1997 to 2005 (Fig. 1). Sampling in the fjords was conducted from the RV 'Oceania', and in the Barents Sea from the RV 'Ivan Petrov'. Details of locations of sampling stations are given in publications based on relevant data sets (Cochrane et al. 2009, Włodarska-Kowalczuk \& Pearson 2004, Renaud et al. 2007, WłodarskaKowalczuk \& Węsławski 2008). Altogether, 388 samples were taken from depths ranging from 22 to $458 \mathrm{~m}$ (Table 1). All samples were collected with a van Veen grab with a $0.1 \mathrm{~m}^{2}$ catching area. The samples were sieved through mesh screens with hole diameters of $0.5 \mathrm{~mm}$ (Kongsfjorden and Hornsund), $0.75 \mathrm{~mm}$ (Barents Sea) or $1 \mathrm{~mm}$ (van Mijenfjorden). Warwick et al. (2006) studied the relationship between the benthic diversity estimates and sizes of sieve meshes and showed that the species diversity of soft-bottom benthic samples did not significantly differ between samples sieved on 1 and $0.5 \mathrm{~mm}$ sieves. We therefore find it reasonable to use the data based on materials sieved on these different mesh sizes in our comparative study. The samples were fixed in formalin and in the laboratory all the animals were sorted, identified to the lowest possible taxonomic level and enumerated. As the focus of this study is the contrast between shelf and fjord soft-substrate habitats, confounding factors such as inherent differences in the availability and nature of hard substrate in these habitats were eliminated. Colonial taxa associated with stones and other hard-bottom substrate elements (Bryozoa and Hydrozoa), and several stations with a high percentage of gravel were not included in the analysis. 
Table 1. Sampling effort and depth ranges of stations used in the present study. All samples were collected using a van Veen grab. The table includes references to papers with details on station locations

\begin{tabular}{|lcccc|}
\hline Region & $\begin{array}{c}\text { Number } \\
\text { of samples }\end{array}$ & $\begin{array}{c}\text { Collection } \\
\text { date }\end{array}$ & $\begin{array}{c}\text { Depth } \\
\text { range (m) }\end{array}$ & Source \\
\hline Barents Sea & 220 & Aug 2003 & $79-458$ & Cochrane et al. (2009) \\
Hornsund & 43 & Aug 2005 & $100-120$ & Włodarska-Kowalczuk \\
Inner & 19 & & $100-115$ & \& Węsławski (2008) \\
Outer & 24 & & $100-120$ & \\
van Mijenfjorden & 44 & Jul 2000/ & $22-105$ & Renaud et al. (2007) \\
Inner & 36 & Jul 2001 & $22-105$ & \\
Outer & 8 & & 68 & \\
Kongsfjorden & 81 & Jul 1997/ & $38-380$ & Włodarska-Kowalczuk \\
Inner & 24 & Jul 1998 & $38-83$ & \& Pearson (2004) \\
Outer & 57 & & $72-380$ & \\
& & & & \\
\hline
\end{tabular}

\section{Data analysis}

The data set contained 388 samples. The fjordic data were divided into subsets representing the outer and inner parts of the fjords. In each fjord, the main bathymetric barrier was identified: in Kongsfjorden, the shallows of Lovénøyanne; in van Mijenfjorden, the sill associated with the island Akseløya; and in Hornsund, the entrance to the inner glacial bay, Brepollen (Fig. 1). The 3 categories used in the analysis of the data set represented the 3 ecological zones: shelf (220 samples, all Barents Sea samples), outer fjords (89 samples) and inner fjords (79 samples).

The patterns of species distribution were explored with use of a non-parametric multivariate analysis. Bray-Curtis similarities were calculated on species abundances in samples. Raw (untransformed), double-square-root transformed and presence/ absence data were used. These provide different views of the community structure-from the view with no transformation when only a few of the most dominant species are decisive for station similarities, to an analysis with presence/absence data, which takes into account all species regardless of their abundance in a sample (Clarke \& Warwick 1994). Non-metric multidimensional scaling (nMDS) was carried out to view the similarities among samples. Formal significance tests for differences between groups of samples collected within 3 ecological zones (shelf, outer fjords and inner fjords) were performed using the one-way ANOSIM test. ANOSIM's R statistic estimates the difference between average rank similarities among pairs of replicates within each of the compared groups and the average rank similarity of replicates between groups (Clarke 1993).
Two spatial scales were considered in analysis and comparisons of species richness in the 3 habitats: (1) the whole ecological zone (habitat species richness), and (2) an individual sample (point species richness; Gray 2000). Habitat species richness was compared using species accumulation curves. Species accumulation curves permit comparisons of the diversity of faunal assemblages at comparable levels of sampling effort. If the 95\% confidence intervals around the observed species richness $\left(S_{\text {obs }}\right)$ for the 3 studied ecological zones do not overlap, then differences are significant at $\mathrm{p}<0.05$ (Colwell et al. 2004). When species accumulation curves fail to reach an asymptote, the non-parametric estimators of the true species richness, Chao1 and Chao2, were calculated (Magurran 2004). $S_{\text {obs, }}$ Chao1 and Chao 2 were computed using EstimateS (Colwell 2005). The comparison of habitat species richness with use of species accumulation curves was also performed for the 4 main taxonomic groups: Polychaeta, Mollusca, Crustacea and Echinodermata.

Sample diversity was estimated at a point scale using a variety of indices. Species richness $(S)$ was defined as the total number of species in a sample. Species diversity was also measured using the Hurlbert rarefaction index (Hurlbert 1971) calculated for 100 individuals (ES(100)) and the Shannon-Wiener log-based index $(H)$. The evenness (equitability) of distribution of individuals among species was calculated as the Pielou index $(J)$. Differences in $S$, $E S(100), H$ and $J$ among 3 zones were tested using the non-parametric Kruskal-Wallis test, as transformations of data did not homogenize variances.

The numbers of species that occurred in 3,2 or only 1 ecological zone were tallied. The analysis was performed on a data set including all recorded species as well as on data sets with the less abundant species excluded, which were either: (1) only species occurring with mean densities of at least 1 ind. $0.1 \mathrm{~m}^{-2}$ in at least one of the groups, or (2) only species occurring with mean densities of at least 5 ind. $0.1 \mathrm{~m}^{-2}$ in at least one of the groups.

Rare species are species restricted in their abundance and spatial range (Gaston 1994). In practice, the selection of rare species is determined by the scale of the ecological study and the sampling techniques. In the present study, rare species were defined as those represented by only one individual 
(singletons) or 2 individuals (doubletons), or occurring in only one sample (uniques) or 2 samples (duplicates). The distribution of species among classes of different frequency of occurrence in samples (i.e. different levels of rarity) was assessed for the 3 ecological zones.

The diversity of functional groups (guilds) was compared among ecological zones. In this study we applied the classical classification of species into functional guilds based on their feeding and mobility traits as proposed by Jumars \& Fauchald (1977). Distribution of these traits was shown to be a good descriptor of responses of benthic communities to various stressors and their functional diversity in terms of resource partitioning and interspecific competition (e.g. Pagliosa 2005). All taxa were classified by their feeding mode and comparative mobility according to Fauchald \& Jumars (1979), Feder \& Matheke (1980), Kuznetsov (1980), other published records and unpublished observations. Guilds representing combinations of 5 feeding types (carnivores, herbivores, suspension feeders, surface detritus feeders and subsurface detritus feeders [burrowers]) and 3 mobility types (sessile, discretely motile and mobile) were considered. The feeding types included species capable of employing 2 or more feeding modes (omnivores). The data matrix of functional guilds abundances in samples was constructed. The relationship between the similarities within the basic data matrix and the functional guilds data matrix (double-square-root data transformation, Bray-Curtis index of similarity) was examined using the Spearman's rank correlation coefficient $\left(\mathrm{r}_{\mathrm{S}}\right)$ computed between corresponding elements of the relevant matrices. The significance of correlation was determined with the Monte Carlo permutation procedure using the RELATE routine in PRIMER (Clarke \& Warwick 1994). The number of guilds and the percentage of each functional group out of the total number of organisms were calculated for each ecological zone. The evenness of distribution of individuals among the functional groups was assessed using the Pielou index. The number of species in a guild is a basic measure of redundancy. However, in natural communities, guilds differ in species richness. For example, in total, we found only 12 species of mobile suspension feeders and as many as 137 species of mobile carnivores. In the present study, for each guild and in each ecological zone we calculated a 'standardized number of species', i.e. (number of species of the guild present in the ecological zone/number of species of the guild recorded in the whole study area) $\times$ 100. Thus, for example, 6 species of mobile suspen- sion feeders and 58 species of mobile carnivores found in outer fiord sediments were standardized into values of 50 and 42 , respectively. In this way we assured comparability of redundancy estimators of guilds with different total species richness. The differences in standardized numbers of species per guild among the 3 ecological zones were identified using a one-way ANOVA (as homogeneity of variance and normality of distribution of data in compared data was confirmed with use of the Shapiro-Wilks test and the Brown-Forsyth test, respectively) and Fisher's least significant difference post hoc tests.

\section{RESULTS}

Very high values of the ANOSIM global R statistic (Table 2) and the distribution of samples on nMDS plots (Fig. 2) indicated that the 3 ecological zones were clearly separated regardless of whether an analysis was oriented towards only species composition (presence/absence data) or also considered species densities (transformed and raw data). The separation of samples collected in inner fjords, outer fjords or shelf stations was stronger than between stations located in Arctic or Atlantic water-dominated areas (i.e. northern or southern regions) of the Barents Sea (nMDS plots, Fig. 2). Very high values of ANOSIM R statistics documented strong differences between the biota inhabiting shelf and both inner and outer parts of fjords (Table 2). Lower values of ANOSIM R statistics for similarities recorded for

Table 2. Results (R-values) of one-way ANOSIM tests of differences between groups of samples collected in the Barents Sea, in the outer and inner parts of the studied fjords. The analysis was performed for the Bray-Curtis similarities of raw data, double-square-root transformed data and presence/ absence data of (A) species abundances and (B) functional guild abundance. All results are significant at $p=0.001$

\begin{tabular}{|lccc|}
\hline & $\begin{array}{c}\text { Raw } \\
\text { data }\end{array}$ & $\begin{array}{c}\text { Double- } \\
\text { square root }\end{array}$ & $\begin{array}{c}\text { Presence } \\
\text { /absence }\end{array}$ \\
\hline A. Species & & & \\
Global test & 0.79 & 0.85 & 0.83 \\
$\begin{array}{l}\text { Pairwise tests } \\
\text { Shelf - inner fjords }\end{array}$ & 0.89 & 0.91 & 0.89 \\
$\quad$ Shelf - outer fjords & 0.86 & 0.88 & 0.87 \\
$\quad$ Inner fjords - outer fjords & 0.47 & 0.67 & 0.60 \\
B. Functional guilds & & & \\
Global test & 0.49 & 0.53 & 0.41 \\
Pairwise tests & & & \\
$\quad$ Shelf-inner fjords & 0.60 & 0.69 & 0.64 \\
Shelf - outer fjords & 0.43 & 0.38 & 0.21 \\
Inner fjords - outer fjords & 0.40 & 0.55 & 0.42 \\
\hline
\end{tabular}




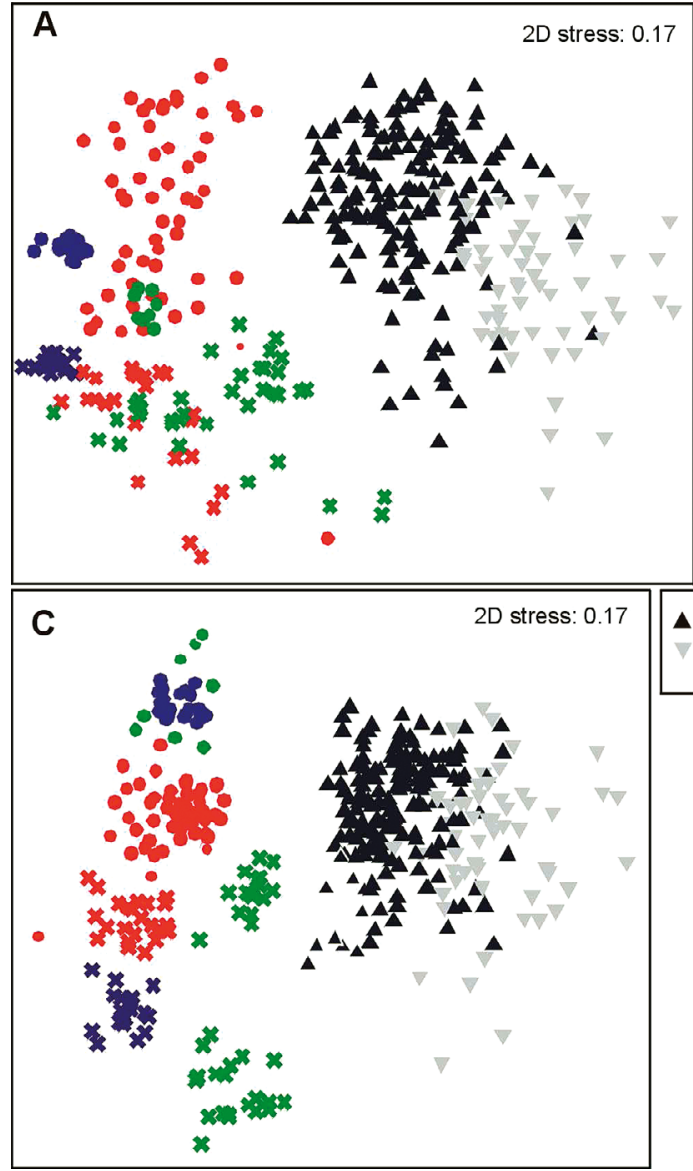

inner and outer fjords indicate that faunas of these 2 habitats are separable, although overlapping to some extent, especially when mostly the abundance of dominant species was taken into account (untransformed data, Table 2). ANOSIM pair-wise test results were highly significant $(p \leq 0.001)$ for all zone combinations (Table 2).

A total of 621 species were identified; 430 in the Barents Sea, 312 in outer fjords and 159 in inner fjords. None of the species accumulation curves leveled off, and for all ecological zones the observed number of species was lower than the estimated (Chao1 and Chao2) true species richness and was outside of $95 \%$ CI of both estimators. Chao1 gave an estimate of 484 species (with $95 \%$ CI from 460 to 530) on the shelf, 366 species (95\% CI from 341 to 413 ) in outer fjords, and 173 species $(95 \%$ CI from 164 to 195) in inner fjords. Chao2 of total richness predicted 500 species (with $95 \%$ confidence intervals from 471 to 551 ) on the shelf, 407 species (95\% CI from 366 to 480 ) in outer fjords, and 196 species (95\% CI from 175 to 241) in inner fjords. $S_{\text {obs, }}$ Chao1 and Chao 2 indicated that total species richness of inner fjords was significantly different (no overlap of $95 \%$ CI)

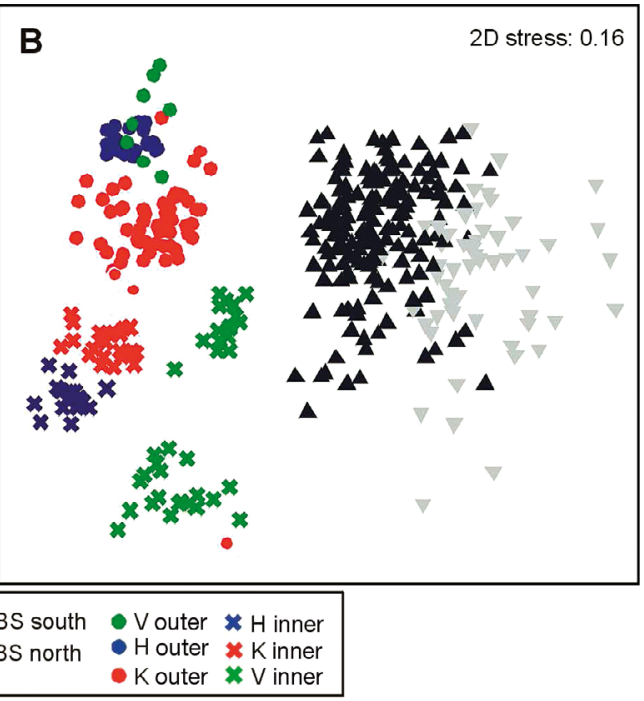

Fig. 2. Non-metric multidimensional scaling plots of BrayCurtis similarities of benthic species densities in samples: (A) untransformed data, (B) double-square-root transformed data and $(\mathrm{C})$ presence/absence data. Symbols represent the sampled localities: BS: Barents Sea; V: van Mijenfjorden; H: Hornsund; K: Kongsfjorden. Inner and outer parts of the fjords as well as southern and northern parts of the Barents Sea (according to Cochrane et al. 2009) are also distinguished

and lower than that in either outer fjord or shelf habitats (Fig. 3). Outer fjord and shelf zones were not distinct in Chao1 or Chao2 and only marginally so for $S_{\text {obs }}$ (Fig. 3). Habitat species richness in areas located behind the bathygraphic barriers (in inner fjords) was significantly lower than in either outer fjords or shelf for the 4 main taxonomic groups (Polychaeta, Mollusca, Crustacea and Echinodermata) as indicated by the respective species-accumulation plots (Fig. 3).

There were significant differences in $S, E S(100), H$ and $J$ among the 3 studied ecological zones (KruskalWallis, $\mathrm{p}<0.001$; Table 3). Post hoc tests identified significant $(\mathrm{p}<0.05)$ differences among all pair-wise zone combinations for $E S(100)$ and $H$. Species richness, species diversity and evenness measures all decreased as one moved from the shelf towards the inner parts of the fjords; however, there were no statistical differences between the shelf and the outer fjords in $S$ or between the outer and inner fjords in $J$ (Table 3, Fig. 4). Hornsund had lower values for all diversity indices in comparable fjord zones except for species richness $(S)$, where it was higher than in outer zones of other fjords (Fig. 4). 

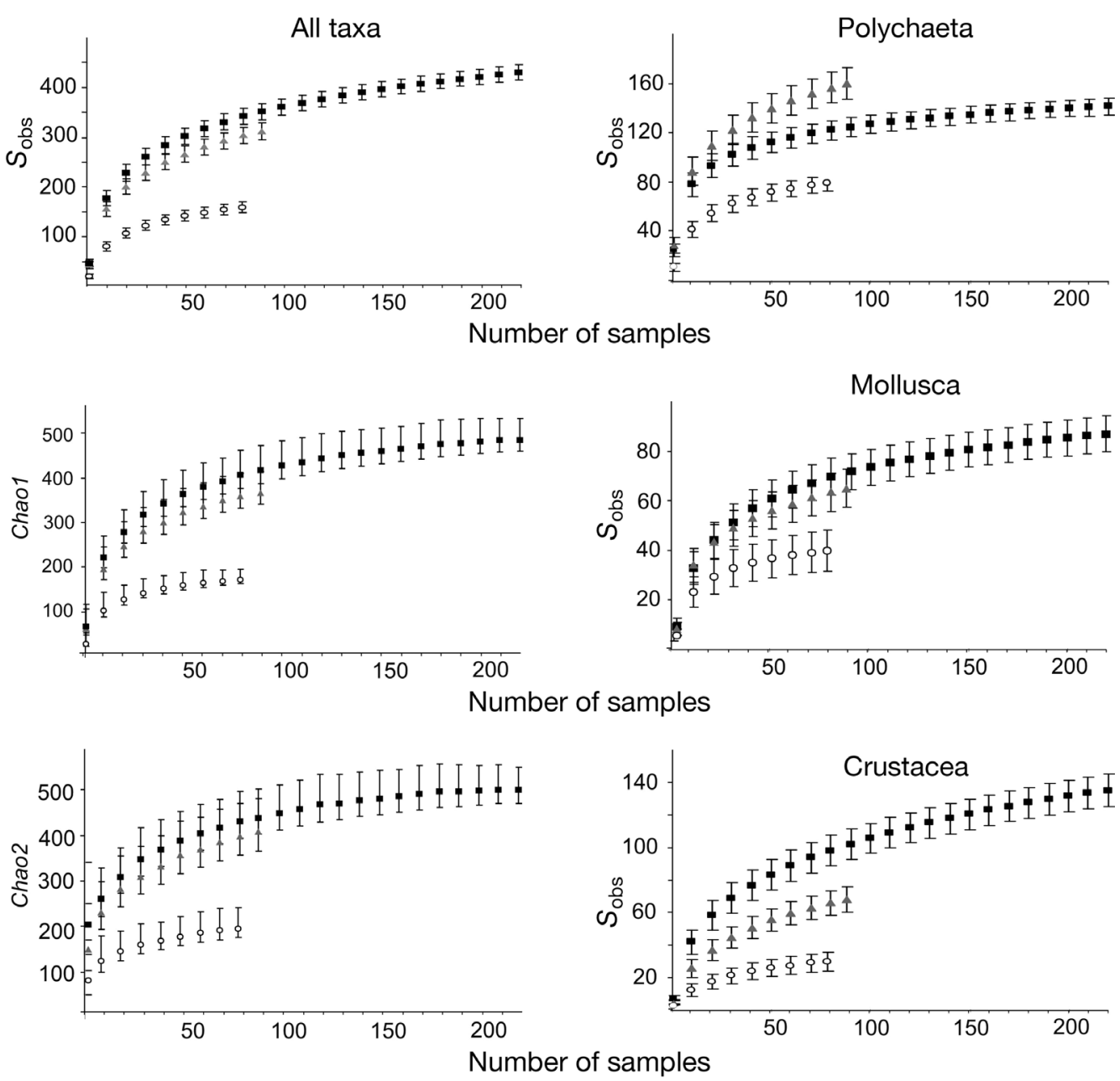

- Shelf $\rightarrow$ Outer fjords $-\infty$ Inner fjords

Fig. 3. Species accumulation curves for shelf, outer fjords and inner fjords. $S_{\text {obs }}$ Chao1 and Chao 2 are plotted for the data set containing all recorded taxa; $S_{\text {obs }}$ is also plotted for selected taxonomic groups: Polychaeta, Mollusca, Crustacea and Echinodermata. $S_{\text {obs }}$ Chao1 and Chao2 are plotted with $95 \%$ confidence intervals. For clarity, only values for every tenth sample are presented. Data are means $\pm 95 \%$ confidence intervals

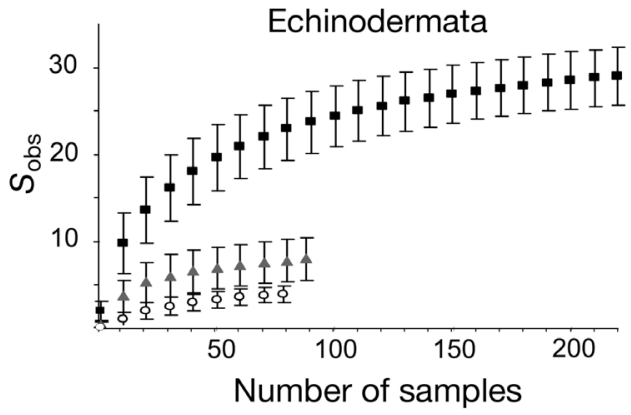

Of all species, $13 \%$ occurred in all 3 zones (Fig. 5); $45 \%$ were found only in the Barents Sea samples, while $31 \%$ were found only in fjords. Only $3 \%$ of species were limited to inner parts of fjords. When only species of mean density (in at least one ecological zone) of at least 1 ind. $0.1 \mathrm{~m}^{-2}$ were considered, $42 \%$ species were common for all 3 zones (Fig. 5), $23 \%$ were restricted to shelf localities and $23 \%$
Table 3. Results of Kruskal-Wallis global test and post hoc pairwise tests comparing macrozoobenthic diversity measures in samples collected in the 3 ecological zones: shelf, outer fjords and inner fjords

\begin{tabular}{|lccl|}
\hline & $H$ & $\mathrm{p}$ & $\begin{array}{l}\text { Significant pairwise } \\
\text { contrasts }(\mathrm{p}<0.05)\end{array}$ \\
\hline No. of species per sample & 135.7 & $<0.001$ & $\begin{array}{l}\text { shelf, outer }>\text { inner } \\
\text { Hurlbert index }(E S(100))\end{array}$ \\
$\begin{array}{llll}\text { Shannon-Wiener index } \\
\text { Pielou evenness index }\end{array}$ & 234.0 & $<0.001$ & sheler $>$ inner \\
& 159.0 & $<0.001$ & shelf $>$ outer $>$ inner \\
shelf $>$ outer, inner
\end{tabular}


SPECIES RICHNESS

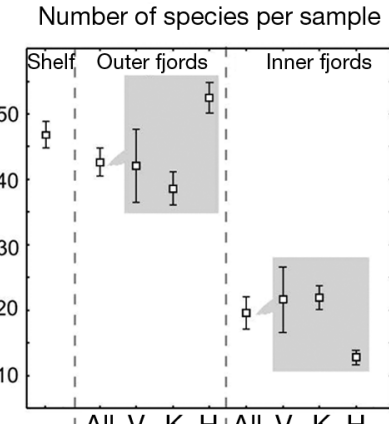

SPECIES DIVERSITY

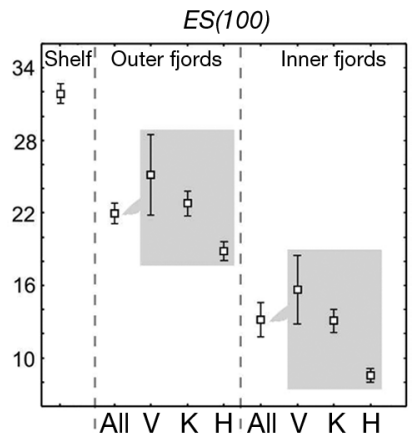

Shannon-Wiener $(\log \mathrm{e})$

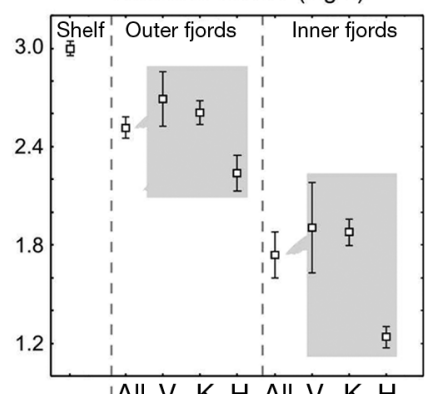

EVENNESS

Pielou index

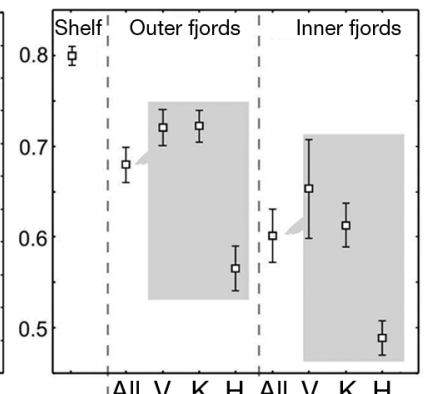

Fig. 4. Mean $( \pm 95 \%$ confidence intervals) values of biodiversity measures: number of species per sample, the Hurlbert index $(E S(100))$, the Shannon-Wiener index and Pielou's index in samples taken from 3 zones: shelf, outer fjords and inner fjords. For outer and inner fjords, boxes and whiskers are plotted both for all samples (all) and for samples from individual fjords (V: van Mijenfjorden; K: Kongsfjorden; H: Hornsund)

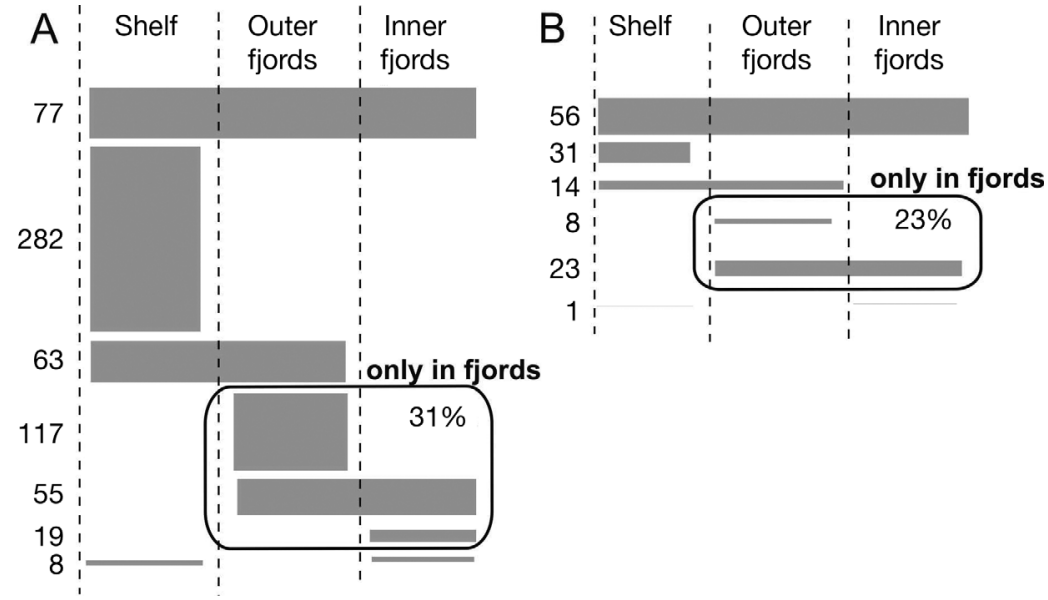

Fig. 5. Numbers of species that were unique to or common to 2 or all of the studied groups of samples: shelf, inner fjords and outer fjords. (A) All species (in total 621) considered; (B) only species occurring with mean densities of at least 1 ind. $0.1 \mathrm{~m}^{-2}$ (mean values for groups of samples, in total 132) considered. The width of the bars is scaled according to species numbers. Percentages of species occurring only in fjords are also indicated

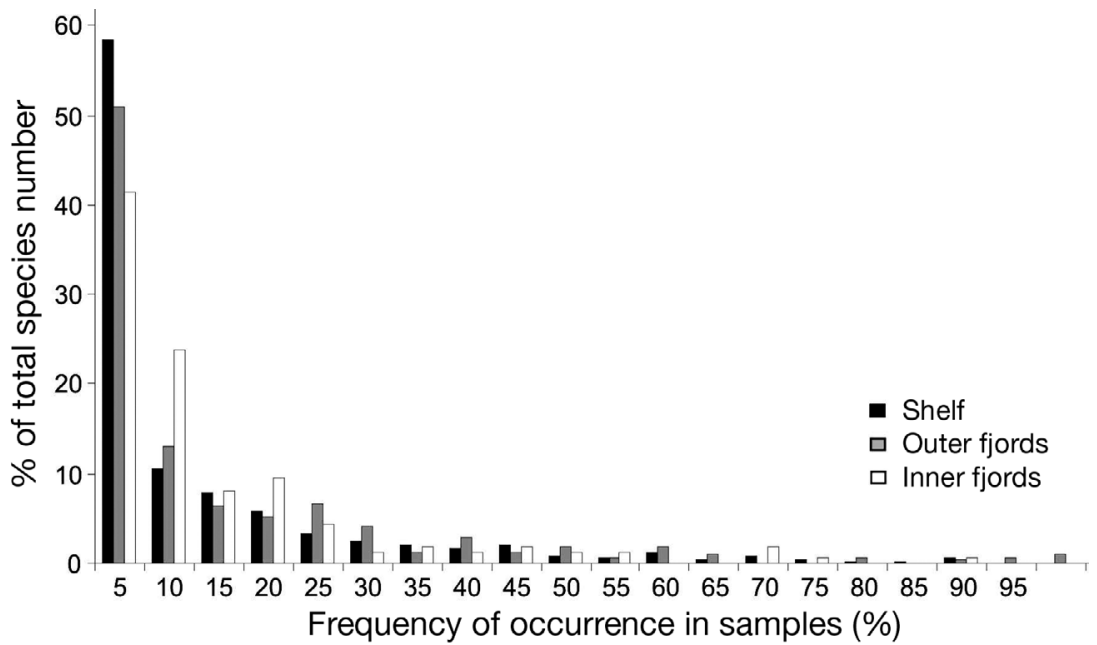

were found only in fjords, but only 1 species $(0.7 \%)$ occurred only in inner fjords.

The distribution of rare species was very similar among the 3 zones, regardless of how rarity was defined (Fig. 6). The singletons and doubletons together made up $29 \%$ of all species recorded in inner fjords, $32 \%$ of species in outer fjords and $26 \%$ of species on the shelf. Uniques and duplicates together made up $35 \%$ of all species recorded in inner fjords, $37 \%$ of species in outer fjords and $32 \%$ of species on the shelf (Table 4).

The communities in the 3 ecological zones were numerically dominated by polychaetes and bivalves (Table 5). The sedentary, tube-dwelling, suspension or surface-detritus-feeding polychaete Spiochaetopterus typicus dominated the fauna in shelf sediments. In fjords, numbers of $S$. typicus dramatically decreased and mobile detritus feeders of the genus Chaetozone strongly dominated benthic communities. Large numbers of minute yoldiid (Yoldiella solidula, Yoldiella lenticula) and thyasirid (Thyasira dunbari) bivalves were characteristic of inner fjordic basins (Table 5).

Fig. 6. Distribution of species among classes of different frequency of occurrence in samples collected in 3 ecological zones: shelf, inner fjords and outer fjords 
Table 4. Numbers of rare species in 3 ecological zones: inner fjords, outer fjords and shelf. Percentages of the total number of species recorded are given in parentheses. Rare species are defined as species represented by only one (singletons) or 2 individuals (doubletons) or occurring in only one (uniques) or 2 samples (duplicates)

\begin{tabular}{|lccc|}
\hline & Inner fjords & Outer fjords & Shelf \\
\hline Singletons & $25(16 \%)$ & $63(20 \%)$ & $70(16 \%)$ \\
Doubletons & $21(13 \%)$ & $37(11 \%)$ & $43(10 \%)$ \\
Uniques & $38(24 \%)$ & $83(26 \%)$ & $86(20 \%)$ \\
Duplicates & $18(11 \%)$ & $36(11 \%)$ & $51(12 \%)$ \\
\hline
\end{tabular}

Table 5. Mean densities (ind. $0.1 \mathrm{~m}^{-2}$ ) of the 10 most numerous species in each of the 3 ecological zones: shelf, outer fjords and inner fjords. The 5 most numerous species are shown in bold. P: polychaete; B: bivalve

\begin{tabular}{|lccc|}
\hline Species & Shelf & $\begin{array}{c}\text { Outer } \\
\text { fjords }\end{array}$ & $\begin{array}{c}\text { Inner } \\
\text { fjords }\end{array}$ \\
\hline Mendicula ferruginosa (B) & $\mathbf{1 7}$ & & \\
Paraninoe minuta (P) & 8 & & \\
Spiophanes kroeyeri (P) & $\mathbf{9}$ & 0 & \\
Spiochaetopterus typicus (P) & $\mathbf{3 1}$ & 1 & 0 \\
Heteromastus filiformis (P) & $\mathbf{1 1}$ & 20 & 1 \\
Galathowenia oculata (P) & $\mathbf{2 6}$ & 4 & 1 \\
Chaetozone complex (P) & 4 & $\mathbf{1 3 9}$ & $\mathbf{1 0 9}$ \\
Yoldiella solidula (B) & 7 & 8 & $\mathbf{5 8}$ \\
Cossura longocirrata (P) & 1 & $\mathbf{4 2}$ & $\mathbf{3 0}$ \\
Maldane sarsi (P) & 8 & 27 & 1 \\
Yoldiella lenticula (B) & 3 & 5 & $\mathbf{2 1}$ \\
Apistobranchus tullbergi (P) & 0 & 20 & 0 \\
Terebellides stroemi (P) & 2 & 10 & 1 \\
Levinsenia gracilis (P) & 1 & 10 & 1 \\
Thyasira gouldi (B) & 4 & 5 & 2 \\
Ennucola tenuis (B) & 0 & 6 & 7 \\
Aglaophamus malmgreni (P) & 2 & 0 & 5 \\
Polycirrus arcticus (P) & 0 & 0 & 6 \\
Axinopsida orbiculata (B) & & 12 & 1 \\
Lumbrineris sp. (P) & & $\mathbf{5 4}$ & 2 \\
Leitoscoloplos mammosus (P) & & $\mathbf{4 2}$ & 1 \\
Prionospio cf. cirrifera (P) & & $\mathbf{3 3}$ & 0 \\
Chone paucibranchiata (P) & & 8 & $\mathbf{1 9}$ \\
Thyasira dunbari (B) & & 1 & 13 \\
Lumbrineris mixochaeta (P) & & 3 & 6 \\
\hline
\end{tabular}

The Spearman rank correlations between the similarity matrices based on species and functional guilds data were significant $(\mathrm{p}=0.001)$, and S-values were high for all transformations of data $(S=0.72$ for untransformed data, $\mathrm{S}=0.70$ for double-square-root transformed data, $\mathrm{S}=0.6$ for presence/absence data). The functional structure of benthic communities differed among the zones. ANOSIM global and pairwise tests results were highly significant $(p \leq 0.001)$, values of $\mathrm{R}$ statistics were lower than in respective analyses performed on the species data matrix, but

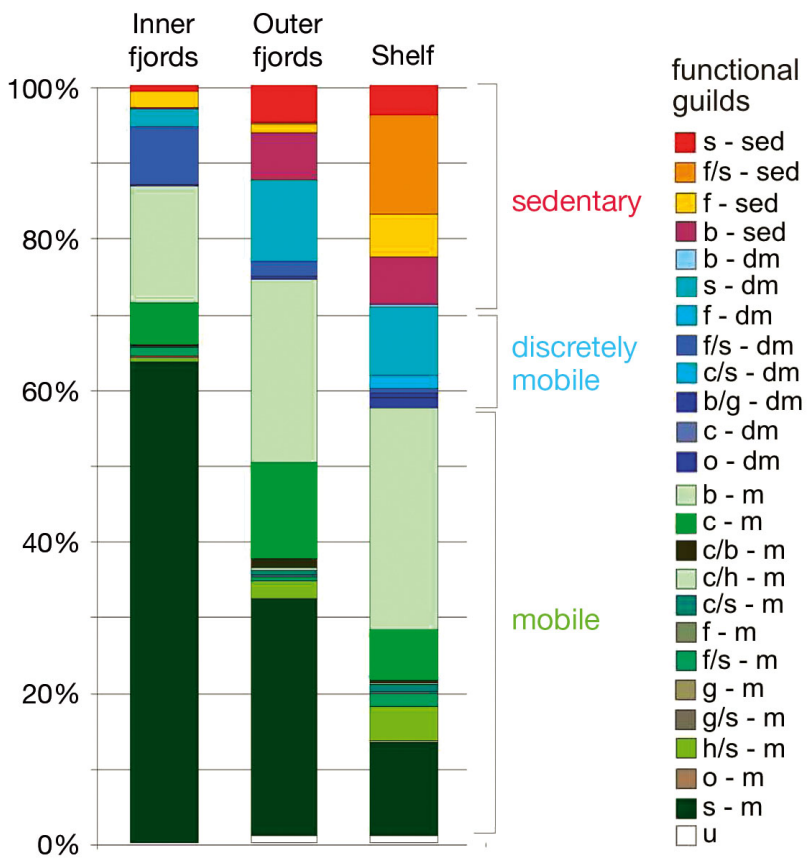

Fig. 7. Percentages of functional types in total numbers of animals collected in the 3 ecological zones. Functional groups are designated by codes: first letter(s) = feeding type: f: suspension feeder; s: surface detritus feeder; b: subsurface detritus feeder; c: carnivore; o: omnivores; last letter(s) = mobility type: $\mathrm{m}$ : mobile, dm: discretely mobile, sed: sedentary; $\mathrm{u}$ : unknown functional type

still indicated a clear separation of the 3 ecological zones (Table 2). Invertebrates representing 20 functional groups were found in inner fjords, 23 in outer fjords and 24 on the shelf (Fig. 7). The evenness of distribution of individuals among the functional guilds declined from shelf to inner fjordic locations: Pielou's index decreased from 0.73 on the shelf and 0.63 in outer fjords to 0.43 in inner fjords. Inner fjord fauna were dominated by one guild, the mobile surface detritus feeders $(63 \%)$; the second most dominant group (mobile subsurface-detritus feeders) comprised $13 \%$ of the fauna. In outer fjords and shelf fauna, the most dominant groups comprised approximately $30 \%$ of all individuals and other groups had considerable shares of total abundances. Numbers of organisms feeding on suspended matter decreased while mobility of the fauna increased towards the inner fjords: suspension feeders and sedentary invertebrates comprised, respectively, $2 \%$ and $3 \%$ of the fauna in inner fjords and $8 \%$ and $29 \%$ of communities on shelf. Redundancy levels varied among the 3 studied ecological zones: e.g. for the most diverse guilds (mobile carnivores, mobile surface deposit feeders and sedentary suspension feeders), the numbers of species were higher in the shelf habitat (94, 


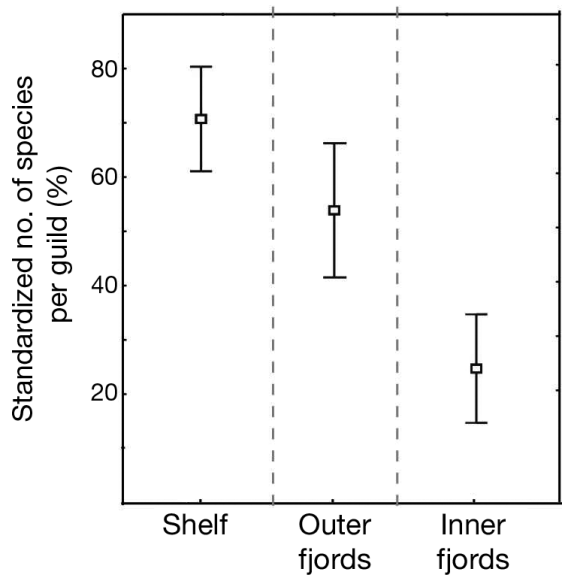

Fig. 8. Mean $( \pm 95 \%$ confidence intervals) values of redundancy (standardized number of species per functional guild) in the 3 ecological zones: shelf, outer fjords and inner fjords

70 and 45$)$ than in the outer fjords $(58,42$ and 26$)$ or inner fjords $(36,21$ or 11, respectively). There were significant differences in standardized numbers of species per guild among the 3 studied ecological zones (one-way ANOVA, $F=20.1, p<0.001$; Fig. 8). Post hoc tests identified significant $(\mathrm{p}<0.05)$ differences among all pair-wise zone combinations.

\section{DISCUSSION}

\section{Mechanisms for establishing species richness patterns between shelf and fjords}

Significant differences between macrobenthic shelf and fjordic communities in the Barents Sea region were documented both for species composition and diversity. The ANOSIM tests and patterns observed on nMDS plots indicate that fjords hosted distinct associations of species both in terms of species lists (analysis of presence/absence data) and structure of dominant species (raw data), and that the differences between fjords and shelf were stronger than contrasts between Arctic and Atlantic water-dominated shelf systems (described by Cochrane et al. 2009). Traditionally, fjordic and estuarine communities have been perceived as subsets of shelf communities (BuhlMortensen \& Höisæter 1993, Josefson \& Hansen 2004), but it is noteworthy that these assertions have not been supported by the comparative analysis of the actual fjordic and offshore sea species lists.

In our study, $30 \%$ of all species recorded occurred only in fjords. The restricted occurrence was not related to abundance of individuals (e.g. only to rare species): $23 \%$ of the most numerous species were not observed in shelf sediments. Thus, even if transport of marine species from the offshore shelf environments sustained the initial colonization and is of basic importance for maintenance of species richness of the fjords, the fjordic species associations are not merely subsets of the offshore species pools. The fjordic species richness is also built by a set of locally occurring fjordic species, many of which must disperse among fjords in shelf or offshore waters but do not become established there. This can be caused by the differences in environmental conditions offered by fjordic and shelf habitats or competitive exclusion by shelf species. One could argue that the studied fjords are located at a considerable distance from the shelf stations, and that this influences the results. However, the sea bottom just outside of the west Spitsbergen fjords is influenced by the strong currents and is covered with gravel and stones. The main basin of the Barents Sea represents the nearest large area of soft-bottom habitat and thus serves as the most likely pool of open shelf species for softbottom communities of the west Spitsbergen fjords.

The patterns of species diversity documented in our study conformed to the often described general pattern of fjordic cline of diversity. This pattern has been reported from a number of fjords located in different geographical regions and differing in the nature of basic environmental gradients driving the biotic patterns and processes. The decrease in both species richness and species diversity was documented in fjords located off Spitsbergen (e.g. Renaud et al. 2007, Włodarska-Kowalczuk et al. 2005), Greenland (Schmid \& Piepenburg 1993, Sejr et al. 2000), the Canadian Arctic (Farrow et al. 1983), Norway (Larsen 1997), Scotland (Gage 1972) and New Zealand (Smith 2001). The diversity clines in fjords are most often explained by either the barrier hypothesis, related to possible colonization barriers posed by fjordic geomorphological features (as sills) or simply the distance to the main species pool located on the shelf, and/or the disturbance hypothesis, i.e. environmental deterioration of the fjordic habitats (BuhlMortensen \& Höisæter 1993).

Lack of congruence of species richness patterns among taxonomic groups with contrasting life histories was considered as a possible indicator of the importance of the offshore species pools and dispersal barriers in setting the diversity patterns in fjords or estuaries. In Danish estuaries, species richness of polychaetes and molluscs (pelagic dispersal) was related to the saltwater flux and/or distance to the open sea, whereas crustaceans (mostly benthic recruiters without a pelagic stage) showed no such 
trends (Josefson \& Hansen 2004). In contrast, BuhlMortensen \& Höisæeter (1993) documented similar patterns for molluscs (dispersal with pelagic larvae) and amphipods (mostly brooders) along offshorefjord transects in Norwegian coastal waters and suggested that dispersal barriers were not responsible for the observed fjordic diversity clines. Similarly, in our study, the significant drop in species richness in inner basins, i.e. behind the bathygraphic barriers, was documented for all major benthic groups, including mostly brooding species (crustaceans) and those with dispersing larvae (polychaetes, molluscs and echinoderms). This pattern suggests that the connectivity to the open-shelf species pool (i.e. the barrier hypothesis) is unlikely to be the main structuring mechanism. However, recruitment of benthic organisms with planktotrophic larvae in glacial fjords can be hampered by other phenomena, including high glacially derived sedimentation and the salinity drop in surface and subsurface waters produced by inflows of fresh glacial meltwaters. Entrainment in the surface low saline waters can be an important source of mortality for larvae and propagules that are not physiologically tolerant of low-salinity conditions (Gage 1972, Smith \& Witman 1999). This would also point to the importance of local environmental filters in explaining shelf-fjord diversity differences.

\section{Species diversity patterns}

The patterns of decline in species diversity across the shelf-fjord environmental gradients differed when the 2 basic diversity aspects (species richness and evenness) were compared. The species richness drop was observed only behind the bathymetric barriers (i.e. only in inner fjords), whereas the evenness was significantly lower in both outer and inner fjords than in shelf sediments. Species richness and evenness constitute 2 different aspects of species diversity, and a number of experimental treatments and in situ ecological studies have shown that a change of one of these 2 basic diversity components is not necessarily accompanied by a parallel change in the other (e.g. Wilsey \& Potvin 2000, Mackey \& Currie 2001, Stirling \& Wilsey 2001). It is still debated which of the two is a better indicator of disturbance or environmental deterioration (Magurran 2004) and which one (if either) can have direct effects on ecosystem functioning (Wilsey \& Potvin 2000). In physically controlled systems, species that are well adapted to thrive in stressed conditions can dominate the community (because of the competitive release after depletion of strong competitors that are less disturbance tolerant), thus decreasing evenness in the communities (Stirling \& Wilsey 2001). The decline in both evenness and species richness (recorded at point scale) in macrobenthic communities has often been attributed to deteriorated environmental conditions in fjords. In temperate fjords, the drop in species diversity and evenness is often linked to oxygen depletion in bottom waters (e.g. Holte et al. 2005), and to differences in sediment heterogeneity between the fjords and shelves (Buhl-Mortensen \& Höisæter 1993, BuhlMortensen 1996). Environmental stress for benthic invertebrates in Arctic glacial fjords is usually produced by the glacial or glaciofluvial inflows. The high load of mineral particles transported by the meltwaters results in high turbidity, high mineral sedimentation rates, frequent disturbance of sediments by gravity flows and iceberg scouring, as well as reduced amounts of organic matter available to benthic invertebrates (Włodarska-Kowalczuk et al. 2005). The magnitude and intensity of these processes increases as one gets closer to the glaciers (most often located in fjord heads) and so the gradual decrease of species evenness along the fjords axis could be expected. Significantly lower evenness in inner fjords compared with outer fjords was observed for each fjord separately (Fig. 4), even if variability among fjords prevented statistical significance when all fjords are combined.

\section{Fjord and shelf functional diversity}

Patterns of distribution of functional guilds in the studied area were quite similar to taxonomic patterns, as indicated by the high Spearman rank correlations between the respective similarity matrices (RELATE procedure). The environmental processes operating in coastal Arctic habitats surveyed in this study resulted in lower functional diversity of the benthic fauna in inner fjordic sediments. Micheli \& Halpern (2005) showed that in communities under chronic environmental disturbance, the functional diversity may be relatively low, as disturbance can remove species/individuals sharing specific functional traits precluding persistence in stressed conditions. Hewitt et al. (2008) observed that betweenhabitat differences in functional composition of soft-bottom benthic communities off New Zealand were driven by differences in species densities rather than presence/absence of individual traits. In west 
Spitsbergen fjordic communities, the simplification of functional diversity was most pronounced in terms of largely decreased functional evenness (i.e. relative densities of functional guilds representatives). Low functional evenness indicates that some part of niche space, whilst occupied, may be under-utilized, which can lead to a decrease of the system's productivity and an increased opportunity for invasion (Mason et al. 2005).

In Arctic fjords, as one moves towards the inner basins, the mobility of the fauna increases and the number of animals feeding on suspended particles decreases. These changes in the benthic fauna can be attributed to sediment characteristics and dynamics. Unconsolidated sediments that are easily eroded and high mineral sedimentation rates are obviously unfavorable for sedentary fauna that can be buried by redeposited sediments as well as for suspension feeders employing filtering appendages that may become clogged by inorganic particles (Moore 1977). Another potentially vulnerable group is tube-dwelling organisms, as the tubes may be buried, thereby impeding irrigation and leading to suffocation. This explains the observed drop in numbers of large tube-dwelling polychaetes in the inner fjord sediments (e.g. Spiochaetopterus typicus, Maldane sarsi). This effect-the removal of tubedwelling large worms (as well as dramatic decreases in epifaunal echinoderm bioturbators) - affects sediment habitat complexity, which can in turn influence the infaunal biodiversity. Similar homogenization of sediment habitats resulting from exclusion of organisms that add 3-dimensional complexity to benthic habitats was previously noted in sediments impacted by heavy commercial fishing (Thrush et al. 1998).

The decrease in functional diversity in inner fjordic basins was accompanied by a decline in species redundancy, i.e. the numbers of species performing similar functions in a system. The biological value of redundancy is still a matter of a debate in the ecological literature. Lawton \& Brown (1993) argued that ecosystem functioning is likely to respond to variations in species richness only when such changes involve the loss or addition of entire functional groups, whereas changes within functional groups will have little effect, and so the biodiversity loss to certain levels can be tolerated. However, even if redundancy does not impact the functioning of a system, it can strengthen its 'resilience', as local extinction of one species can be compensated for by expansion of others within a functional group (Naeem 1998).

\section{Species rarity in fjords and open shelf systems}

The distribution of species among classes of different frequencies of occurrence was strongly skewed to the right, as is commonly observed in both terrestrial and marine ecological systems (Gaston 1994, Ellingsen et al. 2007). Gray et al. (2005) documented the domination of rare species in species-abundance distributions in marine soft-bottom systems explored at various spatial scales. They noted that soft-bottom habitats are populated by small-sized species that do not occupy the whole habitat space available, and are thus open to constant immigrations (resulting in rare species occurrences). For example, proportions of uniques and duplicates recorded in present study (32 to $37 \%$ ) are slightly lower, but roughly comparable to those documented for soft-bottom macrofauna in coastal waters off Norway (32 to $49 \%$; Ellingsen \& Gray 2002), Hong Kong (45\%; Shin \& Ellingsen 2004) and New Zealand (54\%; Ellingsen et al. 2007). The direct functional role of rare species in ecosystems remains largely unexplored, but their importance may stem from the complementarity of species functions and the 'insurance' value of biodiversity that is stored in large numbers of rare species (Loreau et al. 2001).

The distribution of rare species among habitats (which can largely differ from patterns produced by common species) is important for monitoring and conservation planning (Cucherousset et al. 2008). Persistence of rare species is predicted to be very susceptible to anthropogenic disturbances and habitat degradation (Thomas \& Mallorie 1985). In the present study, the proportions of rare species in the 3 ecological zones were similar. The environmental deterioration produced by glacial activity in fjordic basins did not result in reduction of the rare species component of the total richness. This was an unexpected pattern as, for example, Lohrer et al. (2004) showed in experiments that deposition of terrigenous sediment on marine benthic assemblages resulted in species impoverishment, and rare species were eliminated first. Benedetti-Cecchi et al. (2008) documented a strong vulnerability of rare species to environmental variability and disturbances, and systems impacted by human disturbance often exhibit reductions in both diversity and numbers of rare species (e.g. Pearson \& Rosenberg 1978, Thrush 1986, Cao et al. 1998). Maintenance of high proportions of rare species, however, does not necessarily mean that the same rare species persist. Instead, it is possible that new species are continually introduced to inner fjord systems from offshore species pools to replace spe- 
cies, and they survive for only short periods of time. This may be quite different in shelf or outer fjord communities where many of the same species contribute to the rare species pool over time.

\section{CONCLUSIONS}

Our comparative study of Arctic the open shelf and fjords documented clear differences between fjordic and shelf benthic biota in terms of species composition, species richness and diversity, as well as functional complexity and redundancy. The fjordic communities do not seem to be merely subsets of open shelf species pools (as many species were recorded only in fjords), the patterns of fjordic species richness decline are consistent across the major taxa (regardless of the predominant dispersal mode) and the simplification of the functional complexity in fjords is produced by elimination of functional groups that are obviously sensitive to glacial sedimentation - a major agent of environmental deterioration in Arctic fjords. In our view, these observations support the habitat hypothesis, with local environmental filters as main drivers of the impoverishment of fjordic species richness. Detailed studies of genetic relatedness of populations, the dispersal mechanisms of all taxa and the geological history of connectedness are needed to assess the potential role of dispersal barriers. It remains to be explored whether fjords are open systems populated by open sea communities or selfmaintained systems. An understanding of which populations act as sources and which act as sinks is important for conservation and management (Levin 2006), and the connectivity between the fjords and open shelf must be considered for preservation of species richness and functionality in both systems. The differences in the structure of benthic communities of fjords and open shelf sediments that we show here must be considered when developing environmental management strategies for Arctic marine ecosystems. For example, the low species redundancy and uneven distribution of populations among the functional guilds in fjords can imply the higher sensitivity of fjordic ecosystem functioning to both species loss and new species invasions. Further information, such as the role of functional groups in maintaining ecosystem functioning (Micheli \& Halpern 2005), and including an assessment of rare species in biomonitoring (Cao et al. 1998, Lyons et al. 2005, Resh et al. 2005) must be considered, and the results presented here provide a framework for understanding the roles of these metrics in ecosystem assessment.
Acknowledgements. We are grateful for financial support from Akvaplan-niva, the Norwegian Polar Institute, and the Research Council of Norway (no. 190247 to P.E.R.) as well as the Institute of Oceanology PAS and the Polish Ministry of Science and Higher Education (grant no. N 304156937 to M.W.K. and J.M.W.). We also thank C. von Quillfeldt for technical assistance.

\section{LITERATURE CITED}

ACIA (2006) Arctic Climate Impact Assessment - Scientific Report. Cambridge University Press, Cambridge

Benedetti-Cecchi L, Bertocci I, Vaselli S, Maggi E, Bulleri F (2008) Neutrality and the response of rare species to environmental variance. PLoS ONE 3:e2777

Buhl-Mortensen L (1996) Amphipod fauna along an offshore-fjord gradient. J Nat Hist 30:23-49

Buhl-Mortensen L, Höisæeter T (1993) Mollusc fauna along an offshore-fjord gradient. Mar Ecol Prog Ser 97:209-224

Cao Y, Williams D, Williams NE (1998) How important are rare species in aquatic community ecology and bioassessment? Limnol Oceanogr 43:1403-1409

Clarke KR (1993) Non-parametric multivariate analyses of changes in community structure. Aust J Ecol 18:117-143

Clarke KR, Warwick RM (1994) Changes in marine communities: an approach to statistical analysis and interpretation. Natural Environment Research Council, Plymouth Marine Laboratory, Plymouth

> Cochrane SKJ, Denisenko SG, Renaud PE, Emblow CS, Ambrose WG, Ellingsen IH, Skar hamar J (2009) Benthic macrofauna and productivity regimes in the Barents Sea - ecological implications in a changing Arctic. J Sea Res 61:222-233

Colwell RK (2005) EstimateS: statistical estimation of species richness and shared species from samples. Version 7.5. Available at http:/purl.oclc.org/estimates

> Colwell RK, Mao CX, Chang J (2004) Interpolating, extrapolating, and comparing incidence-based species accumulation curves. Ecology 85:2717-2727

Cucherousset J, Santoul F, Figuerola J, Cereghino R (2008) How do biodiversity patterns of river animals emerge from the distributions of common and rare species? Biol Conserv 141:2984-2992

> Death RG (1996) The effect of habitat stability on benthic invertebrate communities: the utility of species abundance. Hydrobiologia 317:97-107

Denisenko SG (2004) Structurally-functional characteristics of the Barents Sea zoobenthos. Proc Zool Inst Russ Acad Sci 300:43-52

> Denisenko SG, Denisenko NV, Lehtonen KK, Andersin AB, Laine AO (2003) Macrozoobenthos of the Pechora Sea (SE Barents Sea): community structure and spatial distribution in relation to environmental conditions. Mar Ecol Prog Ser 258:109-123

Ellingsen KE, Gray JS (2002) Spatial patterns of benthic diversity: Is there a latitudinal gradient along the Norwegian continental shelf? J Animal Ecol 71:373-389

Ellingsen KE, Hewitt JE, Thrush SF (2007) Rare species, habitat diversity and functional redundancy in marine benthos. J Sea Res 58:291-301

Farrow GE, Syvitski JPM, Tunnicliffe V (1983) Suspended particulate loading on the macrobenthos in a highly turbid fjord: Knight Inlet, British Columbia. Can J Fish Aquat Sci 40(suppl):s273-s288 
Fauchald K, Jumars PA (1979) The diet of worms: a study of polychaete feeding guilds. Oceanogr Mar Biol Annu Rev 17:193-284

Feder HM, Matheke GEM (1980) Subtidal benthos, Chapter 9. Port Valdez, Alaska: Environmental Studies 19761979. Institute of Marine Sciences, University of Alaska, Fairbanks, p 237-324

- Gage J (1972) Community structure of the benthos in Scottish sea-lochs. I. Introduction and species diversity. Mar Biol 14:281-297

Gaston KJ (1994) Rarity: population and community biology. Chapman \& Hall, London

- Gray JS (2000) The measurement of marine species diversity, with an application to the benthic fauna of the Norwegian continental shelf. J Exp Mar Biol Ecol 250:23-49

Gray JS, Bjorgesaeter A, Ugland KI (2005) The impact of rare species on natural assemblages. J Anim Ecol 74: 1131-1139

Hewitt JE, Thrush SF, Dayton PD (2008) Habitat variation, species diversity and ecological functioning in a marine system. J Exp Mar Biol Ecol 366:116-122

$>$ Holte B, Oug E, Dahle S (2005) Soft-bottom fauna and oxygen minima in sub-Arctic north Norwegian marine sill basins. Mar Biol Res 1:85-96

$>$ Hurlbert SH (1971) The non-concept of species diversity: a critique and alternative parameters. Ecology 52:577-586

> Huston MA (1999) Local processes and regional patterns: appropriate scales for understanding variation in the diversity of plants and animals. Oikos 86:393-401

> Josefson AB, Hansen JLS (2004) Species richness of benthic macrofauna in Danish estuaries and coastal areas. Glob Ecol Biogeogr 13:273-288

Jumars PA, Fauchald K (1977) Between-community contrasts in successful polychaete feeding strategies. In: Coull BC (ed) Ecology of marine benthos. University of South Carolina Press, Columbia, SC, p 1-22

Kuznetsov AP (1980) Ekologia donnyh soobszczestw szelfovyh zon mirowowo okeana. Isdatelstwo 'Nauka', Moskva

> Larsen LH (1997) Soft-bottom macro invertebrate fauna of North Norwegian coastal basins with particular reference to sill-basins. Part one: bottom topography and species diversity. Hydrobiologia 355:101-113

Lawton JH, Brown VK (1993) Redundancy in ecosystems. In: Schulze ED, Mooney HA (eds) Biodiversity and ecosystem function. Springer Verlag, New York, NY, p 265-270

Levin LA (2006) Recent progress in understanding larval dispersal: new directions and digressions. Integr Comp Biol 46:282-297

Lohrer AM, Thrush SF, Hewitt JE, Berkenbusch K, Ahrens M, Cummings VJ (2004) Terrestrially derived sediment: response of marine macrobenthic communities to thin terrigenous deposits. Mar Ecol Prog Ser 273: 121-138

Loreau M, Naeem S, Inchausti P, Bengtsson J and others (2001) Biodiversity and ecosystem functioning: current knowledge and future challenges. Science 294:804-808

Lyons KG, Brigham CA, Traut BH, Schwartz MW (2005) Rare species and ecosystem functioning. Conserv Biol 19:1019-1024

Mackey RL, Currie DJ (2001) The diversity-disturbance relationship: Is it generally strong and peaked? Ecology 82:3479-3492

Magurran AE (2004) Measuring biological diversity. Blackwell Publishing, Malden, MA
Mason NWH, Mouillot D, Lee WG, Wilson JB (2005) Functional richness, functional evenness and functional divergence: the primary components of functional diversity. Oikos 111:112-118

Micheli F, Halpern BS (2005) Low functional redundancy in coastal marine assemblages. Ecol Lett 8:391-400

Moore PG (1977) Inorganic particulate suspensions in the sea and their effects on marine animals. Oceanogr Mar Biol Annu Rev 15:225-363

> Naeem S (1998) Species redundancy and ecosystem reliability. Conserv Biol 12:39-45

> Olsen GH, Caroll ML, Renaud PE, Ambrose WG Jr, Olsson R, Caroll J (2007) Benthic community response to petroleum-associated components in Arctic versus temperate marine sediments. Mar Biol 151:2167-2176

Pagliosa PR (2005) Another diet of worms: the applicability of polychaete feeding guilds as a useful conceptual framework and biological variable. Mar Ecol 26:246-254

Pearson TH (1980) Macrobenthos of fjords. In: Freeland HJ, Farmer DM, Levings CD (eds) Fjord oceanography NATO Conference. Plenum, New York, NY, p 569-602

Pearson TH, Rosenberg R (1978) Macrobenthic succession in relation to organic enrichment and pollution of the marine environment. Oceanogr Mar Biol Annu Rev 16:229-311

Petchey OL, Gaston KJ (2002) Functional diversity (FD), species richness and community composition. Ecol Lett 5: 402-411

- Renaud PE, Wlodarska-Kowalczuk M, Trannum H, Holte B and others (2007) Multidecadal stability of benthic community structure in a high-arctic glacial fjord (Van Mijenfjord, Spitsbergen). Polar Biol 30:295-305

> Renaud PE, Webb TJ, Bjørgesæter A, Karakassis I and others (2009) Continental-scale patterns in benthic invertebrate diversity: insights from the MacroBen database. Mar Ecol Prog Ser 382:239-252

Resh VH, Beche LA, McElravy EP (2005) How common are rare taxa in long-term benthic macroinvertebrate surveys? J N Am Benthol Soc 24:976-989

Ricklefs RE (1987) Community diversity: relative roles of local and regional processes. Science 235:167-171

Schmid MK, Piepenburg D (1993) The benthos zonation of the Disko Fjord, West Greenland. Medd Gronl 37:1-21

Sejr MK, Jensen KT, Rysgaard S (2000) Macrozoobenthic community structure in a high-arctic East Greenland fjord. Polar Biol 23:792-801

Sirenko BI (2001) List of species of free-living invertebrates of Eurasian Arctic seas and adjacent deep waters. Explor Fauna Seas St Petersburg 51:1-129

Shin PKS, Ellingsen KE (2004) Spatial patterns of softsediment benthic diversity in subtropical Hong Kong waters. Mar Ecol Prog Ser 276:25-35

Smith F (2001) Historical regulation of local species richness across a geographic region. Ecology 82:792-801

Smith F, Witman JD (1999) Species diversity in subtidal landscapes: maintenance by physical processes and larval recruitment. Ecology 80:51-69

Somerfield PJ, Arvanitidis C, Faulwetter S, Chatzigeorgiou $G$ and others (2009) Assessing evidence for random assembly of marine benthic communities from regional species pools. Mar Ecol Prog Ser 382:279-286

Stirling G, Wilsey B (2001) Empirical relationship between species richness, evenness, and proportional diversity. Am Nat 158:286-299

Syvitski JPM, Burrell DC, Skei JM (1987) Fjords. Processes and products. Springer-Verlag, New York, NY 
Syvitski JPM, Andrews JT, Dowdeswell JA (1996) Sediment deposition in an iceberg-dominated glacimarine environment, East Greenland: basin fill implications. Global Planet Change 12:251-270

Thomas CD, Mallorie HC (1985) Rarity, species richness and conservation: butterflies of the Atlas Mountains in Morocco. Biol Conserv 33:95-117

Thrush SF (1986) The sublittoral macrobenthic community structure of an Irish sea-lough: effect of decomposing accumulations of seaweed. J Exp Mar Biol Ecol 96: 199-212

Thrush SF, Hewitt JE, Cummings VJ, Dayton PK and others (1998) Disturbance of the marine benthic habitat by commercial fishing: impacts at the scale of the fishery. Ecol Appl 8:866-879

Trusel LD, Powell RD, Cumpston RM, Birgham-Grette J (2010) Modern glacimarine processes and potential future behavior of Kronebreen and Kongsvegen polythermal tidewater glaciers, Kongsfjorden, Svalbard. Geol Soc Lond Spec Publ 344:89-102

Warwick RM, Dashfield SL, Somerfield PJ (2006) The integral structure of a benthic infaunal assemblage. J Exp Mar Biol Ecol 330:12-18

Wilsey BJ, Potvin C (2000) Biodiversity and ecosystem functioning: importance of species eveness in an old field. Ecology 81:887-892

Winkelmann D, Knies J (2005) Recent distribution and accu-

Editorial responsibility: Lisandro Benedetti-Cecchi, Pisa, Italy mulation of organic carbon on the continental margin west off Spitsbergen. Geochem Geophys Geosyst 6: Q09012 doi:10.1029/2005GC000916

Witman JD, Etter RJ, Smith F (2004) The relationship between regional and local species diversity in marine benthic communities: a global perspective. Proc Natl Acad Sci USA 101:15664-15669

Włodarska-Kowalczuk M, Pearson TH (2004) Soft-bottom macrobenthic faunal associations and factors affecting species distributions in an Arctic glacial fjord (Kongsfjord, Spitsbergen). Polar Biol 27:155-167

Włodarska-Kowalczuk M, Węsławski JM (2001) Impact of climate warming on Arctic benthic biodiversity: a case study of two Arctic glacial bays. Clim Res 18:127-132

Włodarska-Kowalczuk M, Węsławski JM (2008) Mesoscale spatial structures in soft-bottom macrozoobenthos communities: effects of physical control and impoverishment. Mar Ecol Prog Ser 356:215-224

Włodarska-Kowalczuk M, Pearson TH, Kendall MA (2005) Benthic response to chronic natural physical disturbance by glacial sedimentation in an Arctic fjord. Mar Ecol Prog Ser 303:31-41

Zajączkowski M, Włodarska-Kowalczuk M (2007) Dynamic sedimentary environments of an Arctic glacier-fed river estuary (Adventfjorden, Svalbard). 1. Flux, deposition and dynamics of the sediments. Estuar Coast Shelf Sci 74:285-296

Submitted: November 8, 2011; Accepted: May 31, 2012 Proofs received from author(s): August 16, 2012 